\title{
Sex Differences in Oral Pathologies at the Late Classic Maya Site of Xcambó, Yucatán'
}

\author{
Andrea Cucina ${ }^{1 *}$, Vera Tiesler Blos ${ }^{1}$ and Thelma Sierra Sosa ${ }^{2}$ \\ ${ }^{1}$ Facultad de Ciencias Antropológicas, Universidad Autonoma de Yucatán, Mérida. Yucatán \\ ${ }^{2}$ Centro INAH Yucatán, Mérida, Centro INAH Yucatán, Mérida, Yucatán
}

ABSTRACT The present study compares the frequency of oral pathologies - namely caries, antemortem tooth loss and periapical defects - between sexes in the Maya site of Xcambó, Yucatán, during the Late Classic Period (AD 600-900). There are marked differences in the occurrence of oral pathological conditions between the sexes in two of three major areas of the sites, despite evidence of archaeological and funerary homogeneity within the site. In these two compounds, females are significantly more affected by oral pathologies than males. In contrast, the third area of the site shows slightly higher frequencies in males, but with no significant sex difference. The results

Oral pathologies are tightly related to subsistence patterns and they are utilized in anthropological studies as a means to assess diet and food preparation techniques (Powell, 1985; Lukacs, 1989; Larsen et al., 1991; Larsen, 1997; Hillson, 2000).

In ancient Maya society, diet has been investigated in several ways and under various perspectives, related to the "Maya Collapse" and to the shift from the Preclassic to the Classic and Postclassic periods (Whittington and Reed, 1997a; White, 1999). Studies of oral pathologies and of stable isotopes have indicated dietary heterogeneity between sites (Sanders and Price, 1968; Gerry and Krueger, 1997) although a common pattern shared by the whole Maya society was its strong reliance on maize (Landa, 1566; Lentz, 1991; Gerry and Krueger, 1997; White, 1997). Sex differences have been taken into account in the assessment of diet, though often without analyzing and interpreting the data within a more complex socioeconomic and cultural framework. At Copán for example, only the commoner portion of the society was investigated. Females showed higher frequency of caries than males, and this was explained as the result of a higher intake of carbohydrates and a less diversified diet in the formers (Whittington and Reed, 1997b; Whittington, 1999).

The present study reports preliminary findings on differences in the occurrence of oral pathologies by sex and compounds in the Classic Maya site of Xcambó (AD

\footnotetext{
${ }^{1} \mathrm{~A}$ version of this paper was presented at the XVI Simposio de Investigaciones Arqueologicas en Guatemala. Guatemala City, July 15-19, 2002.
}

have been interpreted according to the site's location, size and economic role within a larger trade network in the Yucatán peninsula. The higher frequency of oral pathologies in females is interpreted as the result of sex differences in dietary and behavioral patterns. Females likely had more maize in their diet and, because of their role in food preparation, may have ingested food more frequently during the day. At the same time, the lack of difference between sexes in the third area of the site contradicts the archaeological evidence of intrasite homogeneity, and it raises questions on the cultural complexity of this population.

300-900) from Northern Yucatán peninsula (México) (Fig. 1). The site was a center for salt production and trade (Sierra Sosa, 1999), strategically located next to the coast on a natural small mound surrounded by marshlands, not far from the town of Dzibilchaltún. The site's economical and geographical characteristics and the provenience of the remains from different areas (i.e., compounds) within the site made the sample interesting to with respect to the analysis of social and sexual aspects of the occurrence of oral pathologies in males and females within and between compounds. This paper aims at answering research questions in terms of social structure and the population's internal composition.

This study is part of a broader project on population relationships and lifestyles of this population as a unit and as part of a larger social and economic regional network. The network orbited around Dzibilchaltún but expanded as far as Guatemala to the south and Veracruz to the west because of its role in salt production and trade (Sierra Sosa and Martínez Lizarraga, 2001).

\section{MATERIALS AND METHODS}

The human skeletal remains currently available for analysis consists of a sample of 200 individuals, of which only 150 possess permanent dentition and/or dental bony support. Most individuals $(\mathrm{N}=129)$ belong to the Late Classic period (AD 600-900), the others are from to the Early Classic period (AD 300-600). The remains were grouped

${ }^{*}$ Correspondence to: Andrea Cucina, Facultad de Ciencias Antropológicas, Universidad Autonoma de Yucatán, Mérida, Yucatán, Mexioco. E-mail: acucina@yahoo.com 


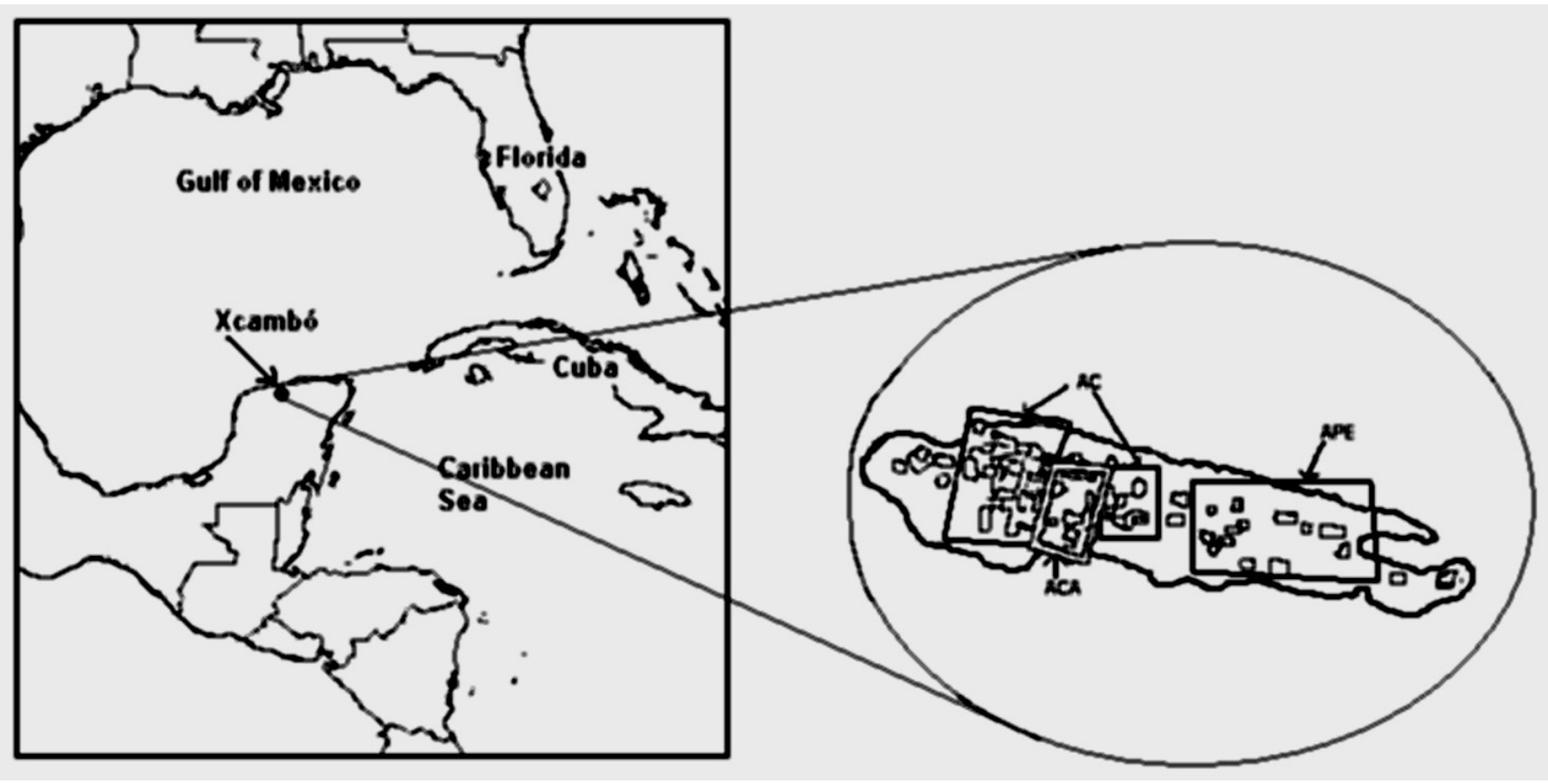

Fig. 1. Geographical location of the site and close up of the site and compounds.

and analyzed according to sex and burial placement. Three major compounds where distinguished: the Central Compound (Asentamiento Central; AC), the Central-Administrative Compound (Asentamiento Central Administrativo; ACA) and the patio groups to its east (Asentamiento Periférico Este; APE) (Fig. 1). In all, the sample totals 2676 permanent teeth. Since this investigation focuses on oral pathologies between sexes, only the adult, sexed individuals and their teeth have been used, and the numbers are listed in Table 1. For obvious reasons, these values are lower than the total ones. All permanent teeth and tooth sockets of the adult sexed individuals were evaluated for oral pathologies according to the methods of Metress and Conway (1975) and Marafon (1976), and following the discussion in Buikstra and Ubelaker (1994).

Caries were scored on each permanent tooth and registered as present when the cavity had reached the dentine and could be clearly detected both visually and with a dental probe. The number of teeth affected and the total available for analysis are listed in Table 2.

Antemortem tooth loss (AMTL) was calculated only on the basis of remodeled tooth sockets in comparison with non-remodeled ones to reduce the bias introduced by poor bone preservation and the associated underestimation of teeth lost during life. Their values and frequencies are reported in Table 3.

Periapical defects appear as round enlargements due to inflammatory processes and bone remodeling. The defects are characterized by smooth homogeneous surfaces on the apical part of the alveolar socket (Marafon, 1976; Lukacs, 1989). These defects were registered as "present" when they could be detected at the apical extremity either because the inflammation had destroyed the external bony tissue or because it was possible to remove the tooth from the jaw and investigate the socket. All the other cases were recorded as "absent". Lukacs (1989) reported that this procedure may underestimate the actual frequency of defects, but in the case of Xcambó the few teeth that could not be removed were not associated with caries and were not affected by heavy occlusal wear, which makes them likely to represent "healthy" sockets. The final values and frequencies for this type of pathological condition are listed in Table 4.

\section{The site}

The occupational sequence at Xcambó starts in the Preclassic period (AD 100-250). During the Early (AD 300-600) and Late (AD 600-900) Classic, Xcambó became a thriving center of salt production and trade (Sierra Sosa, 1999). The site, which is 700 meters long and 150 wide, was constructed on top of an artificially elevated, single large platform emerging from the swampy marshland. Canals and trails connected Xcambó with both the coastal strip and the inland areas. The small size of the site and the characteristics of the natural

TABLE 1. Number of individuals analyzed for caries, AMTL and periapical defects according to sex

\begin{tabular}{lccc}
\hline & Caries & AMTL & $\begin{array}{c}\text { Periapical } \\
\text { Defects }\end{array}$ \\
\hline Males & 62 & 63 & 62 \\
Females & 37 & 39 & 34 \\
\hline
\end{tabular}


TABLE 2. Number of teeth affected by caries, total number of scorable teeth available and percent affected

\begin{tabular}{|c|c|c|c|c|c|c|c|c|c|}
\hline & \multicolumn{3}{|c|}{ Anterior $^{1}$} & \multicolumn{3}{|c|}{ Posterior $^{2}$} & \multicolumn{3}{|c|}{ Anterior + Posterior } \\
\hline \multicolumn{10}{|c|}{$\mathrm{ACA}$} \\
\hline Males & 3 & 87 & 3.4 & 19 & 158 & 12.0 & 22 & 245 & 9.0 \\
\hline Females & 13 & 42 & 31.0 & 25 & 62 & 40.3 & 38 & 104 & 36.5 \\
\hline \multicolumn{10}{|c|}{$\mathrm{AC}$} \\
\hline Males & 14 & 276 & 5.1 & 88 & 457 & 19.3 & 102 & 733 & 13.9 \\
\hline Females & 31 & 99 & 24.0 & 58 & 177 & 32.8 & 89 & 276 & 32.2 \\
\hline \multicolumn{10}{|c|}{ APE } \\
\hline Males & 6 & 47 & 12.8 & 20 & 101 & 19.8 & 26 & 148 & 17.6 \\
\hline Females & 2 & 40 & 5.0 & 11 & 76 & 14.5 & 13 & 116 & 11.2 \\
\hline Total & 69 & 591 & 11.7 & 221 & 1,031 & 21.4 & 290 & 1,622 & 17.9 \\
\hline
\end{tabular}

${ }^{1}$ Anterior teeth are incisors and canines

${ }^{2}$ Posterior teeth are premolars and molars

mound limited the expansion of its monumental religious and administrative center and the associated domestic areas (Sierra Sosa, 1999; Sierra Sosa and Martínez Lizarraga, 2001).

Extensive and intensive archaeological surveys at the site were performed between 1996 and 2000 by the National Institute of Anthropology and History (INAH). In the course of the excavations more than 600 burials were retrieved from both the residential compounds and the central structures. Findings indicate a relative abundance and homogeneity in the distribution of funerary objects associated with the skeletons compared to other sites in the area. This, along with architectural homogeneity, points towards limited internal social differentiation at Xcambó (Sierra Sosa and Martínez Lizarraga, 2001).

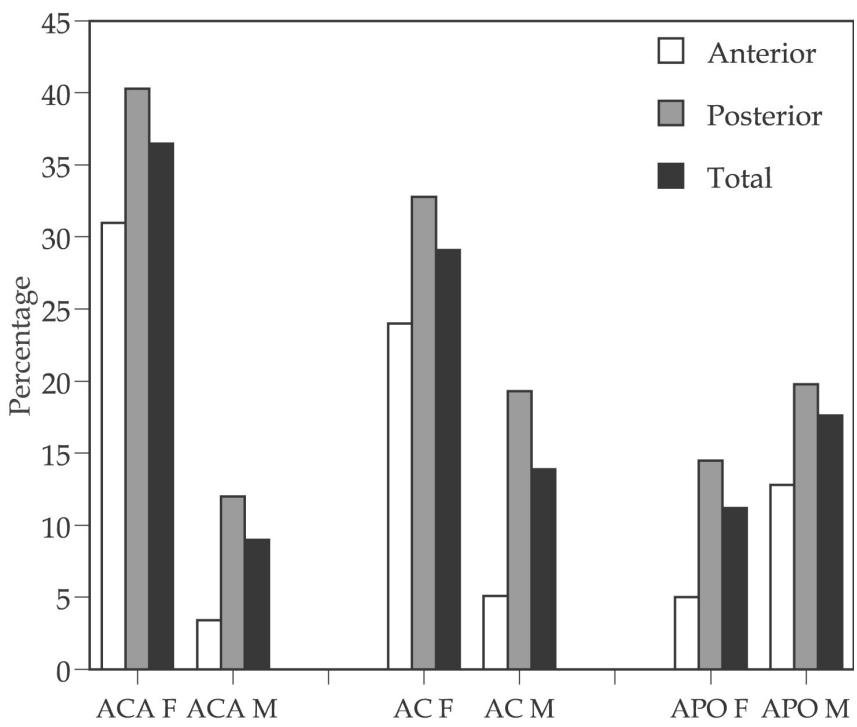

Fig. 2. Frequency of caries according to sex and compounds of the site

\section{RESULTS}

Tables 2 through 4 list the sample sizes and the frequencies of caries, AMTL and periapical defects divided by sex and compounds of Xcambó. The same values are graphically represented in Figures 2 through 4. Some from the three compounds belonged to the early Classic period, but the majority were from the Late Classic. Individuals were not differentiated according to chronological horizon because of the small number of individuals from the Early Classic period, and because any chi-square analysis run between the subsamples did not indicate statistically significant differences between the periods. The only case where a difference was significant significantly was the frequency of AMTL in the males from the AC compound ( $p$ values from chi-square test with one degree of freedom were 0.011 anterior dentition, 0.011 posterior dentition, and 0.000 total). In this case, as in Table 3 and Figure 3, the two periods have been considered separately.

The age distribution within each subgroup was similar and differences were not statistically significant among compounds. For this reason, we could rule out age at death as a factor influencing the rate of oral pathologies in the between-groups analysis.

Sex differences were evident for all the pathological conditions. Females showed much higher frequencies of oral pathologies than males, with the one exception of the APE compound. In this case, males surpass females. Chi-square $\mathrm{P}$ values for all the possible pairwise comparisons are listed in Table 5. Differences between sexes were significant for the three pathological conditions in ACA and AC but not significant in APE. Within-sex comparison shows that the major changes in frequency are encountered between APE and the two other groups. Females at APE are constantly and significantly less affected than their counterparts in the two other compounds. In turn, no difference 


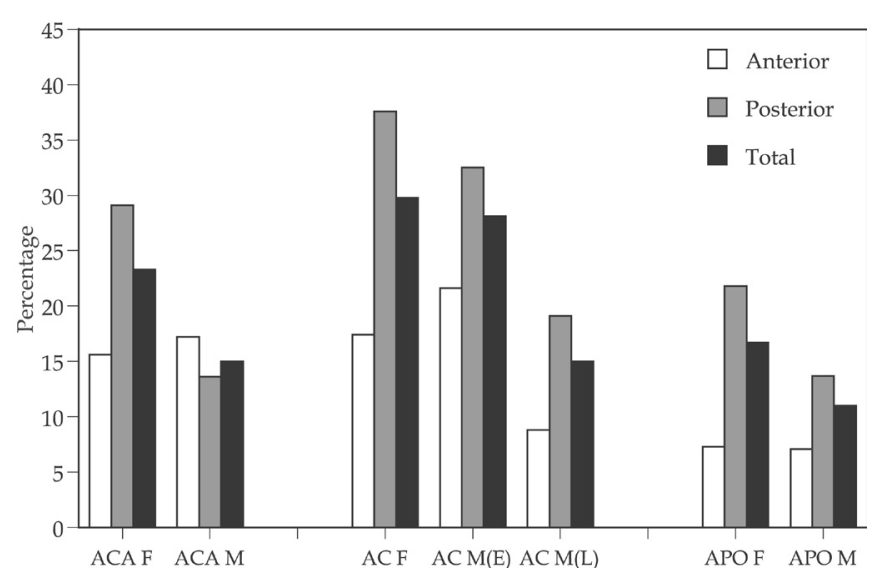

Fig. 3. Frequency of antemortem tooth loss by sex and compounds (Males have been sorted by period: $M(E)$ Early Classic, M(L) Late Classic.)

was encountered in males from the later period among compounds. Caries differences are significant only between ACA and APE. The most noteworthy, significant differences occur when the AC early males are compared for AMTL with the other later males. In this case differences are always significant both in comparison with the other compounds and within AC.

\section{DISCUSSION}

Data on the distribution of oral pathologies by sex at Xcambó reveal some interesting tendencies. The first is that females in general were much more often affected by oral pathologies than males, and the second is that this pattern is common throughout the whole site with the exception of one particular area, the Asentamiento Periferico Este (APE), which shows the opposite tendency.

Several researchers suggest that females are often affected by a higher frequency for oral pathologies than

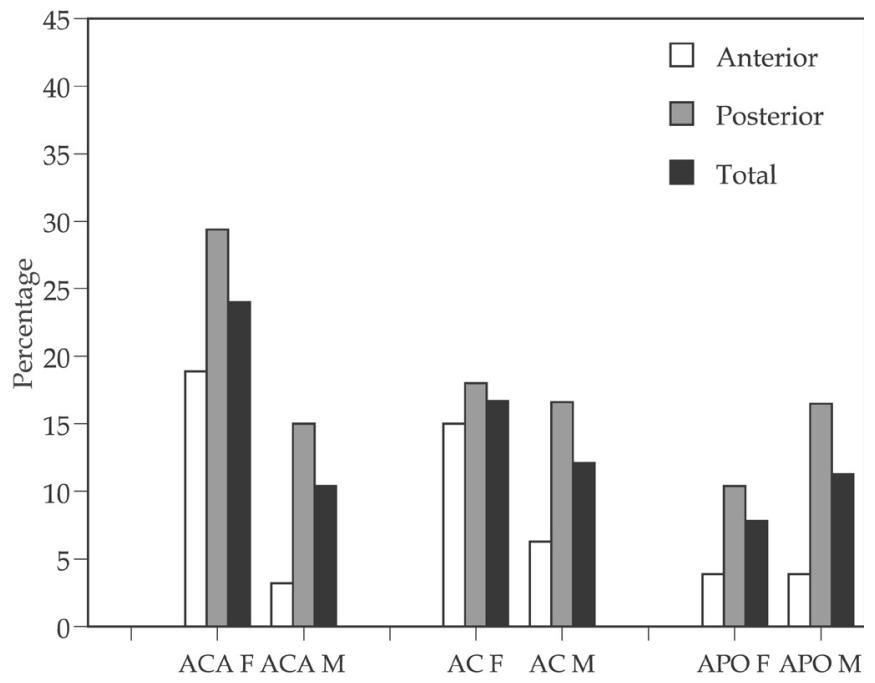

Fig. 4. Frequency of periapical defects by sex and compounds of the site. males (Larsen et al., 1991; Larsen, 1997; Whittington and Reed, 1997b; Storey, 1999; Whittington, 1999). The interpretations encompass a large range of hypothesized causes: differences in diet between males and females, increased susceptibility in the latter, ad a longer time for pathologies to occur in females (given their earlier age of dental eruption and longer life span). A specific cause alone is not sufficient, and every situation is unique in terms of reasons underlying the frequency of oral pathologies (Powell, 1985).

Larsen et al. (1991) noted that major differences between periods in the archaeological samples from the Georgia coast area occurred after the shift in diet from hunting and gathering to agriculture and were not related to age at death. In the sample from Xcambó, age at death does not differ among compounds or between males and females, which rules out the possibility that higher frequencies might be related to longer exposure to cariogenic agents. Moreover, the archaeological evidence indicates that the population of Xcambó was socially homogeneous (Sierra Sosa and Martinez Lizarraga, 2001). Differences are mainly between sexes and not between compounds. This homogeneity excludes marked social stratification as one possible cause for different frequencies of oral pathologies, in contrast with what suggested for the Maya site of Calakmul (Cucina and Tiesler, 2002). Thus, the causes of the differences encountered between sexes should be sought in the kind of diet and/or behavioral and cultural patterns. Indeed, we think that the sex differences are multifactorial in nature and are likely to be related to the characteristics of the site. The site of Xcambó was small in size but an economically important center of salt production and trade (Sierra Sosa, 1999). The site's limited boundaries forced those committed to salt production to work outside the residential area. In most societies, males are those who do the manual labor and females are responsible for the household and food preparation. A model where men and women experience different types of nutrition, where males receive more protein in their diet because of the heavyduty labor, explains their lower rate of cavities (Lee and DeVore, 1968; Larsen et al., 1991). Females might have been exposed to oral pathologies because of a diet where carbohydrates prevailed and because of a more frequent ingestion of food during the day. Larsen and colleagues (1991) pointed that the higher frequency of oral pathologies in females could be attributed to their engagement in food preparation, resulting in more frequent ingestion of food during the day, in comparison to males who may have eaten the same kind food but at specific hours during the day.

The individuals from the APE compounds show a different pattern. Cultural differences may be at the base of such discrepancy, in particular with respect to females' activities, even though the archaeological record does not reveal evidence that would support 
TABLE 3. Number of sockets indicating AMTL, number of total sockets and frequency of AMTL

\begin{tabular}{|c|c|c|c|c|c|c|c|c|c|}
\hline & \multicolumn{3}{|c|}{ Anterior } & \multicolumn{3}{|c|}{ Posterior } & \multicolumn{3}{|c|}{ Total } \\
\hline & AMTL & $\mathrm{n}$ & $\%$ & AMTL & $\mathrm{n}$ & $\%$ & AMTL & $\mathrm{n}$ & $\%$ \\
\hline \multicolumn{10}{|c|}{ ACA } \\
\hline Males & 20 & 116 & 17.2 & 25 & 184 & 13.6 & 45 & 300 & 15.0 \\
\hline \multirow{2}{*}{\multicolumn{10}{|c|}{ AC }} \\
\hline & & & & & & & & & \\
\hline Males E & 11 & 51 & 21.6 & 25 & 77 & 32.5 & 36 & 128 & 28.1 \\
\hline Males L & 30 & 342 & 8.8 & 100 & 523 & 19.1 & 130 & 865 & 15.0 \\
\hline Females & 35 & 201 & 17.4 & 120 & 319 & 37.6 & 155 & 520 & 29.8 \\
\hline \multicolumn{10}{|c|}{$\mathrm{APE}$} \\
\hline Males & 6 & 85 & 7.1 & 17 & 124 & 13.7 & 23 & 209 & 11.0 \\
\hline Females & 4 & 55 & 7.3 & 22 & 101 & 21.8 & 26 & 156 & 16.7 \\
\hline Total & 116 & 914 & 12.7 & 334 & 1414 & 23.6 & 450 & 2328 & 19.3 \\
\hline
\end{tabular}

the difference between APE females from the others. Nonetheless, the small size of the APE sample does not allow us to draw clear conclusions, and the data may result from sampling bias. A more thorough assessment will be possible when all the remains are studied. Similarly, a chronological interpretation of the differences encountered in the frequency of AMTL in the males from the AC group is not conclusive at this time because of the small size of the early Classic sample.

\section{CONCLUSIONS}

In conclusion, this preliminary analysis of oral pathologies from the site of Xcambó reveals interesting evidence that may link cultural and dietary factors to the geographical location and physical structure of the site as a unit, and as part of a wider, more complex economic and trade network. The different results obtained from the various compounds seem to contradict the homogeneity encountered at the archaeological level. Although this can be due to the small sample size of
APE, it will stimulate further analyses addressing the biological and cultural complexity of the dynamic Maya population in Yucatán.

\section{LITERATURE CITED}

Buikstra JE, Ubelaker DH. 1994. Standards for data collection from human skeletal remains. Fayetteville: Arkansas Archaeological Survey Research Series 44.

Cucina A, Tiesler V. 2002. Dental caries and antemortem tooth loss in the northern Peten area, Mexico: a biocultural perspective on social status differences among the Classic Maya. Am J Phys Anthropol 119: (in publication).

Gerr JP, Krueger HW. 1997. Regional diversity in classic Maya diet. In Whittington SL, Reed DM, editors. The bones of the Maya. Washington: Smithsonian Institution Press. p 196-207.

Hillson S. 2000. Dental pathology. In: Katzenberg MA, Saunders SR, editors. Biological anthropology of the human skeleton. New York: Wiley-Liss. p 249-286.

TABLE 4. Number of sockets showing periapical defects, total number of scorable sockets, and the frequency of these defect

\begin{tabular}{|c|c|c|c|c|c|c|c|c|c|}
\hline & \multicolumn{3}{|c|}{ Anterior } & \multicolumn{3}{|c|}{ Posterior } & \multicolumn{3}{|c|}{ Total } \\
\hline & Present & $\mathrm{n}$ & $\%$ & Present & $\mathrm{n}$ & $\%$ & Present & $\mathrm{n}$ & $\%$ \\
\hline \multicolumn{10}{|c|}{ ACA } \\
\hline Males & 3 & 93 & 3.2 & 22 & 147 & 15.0 & 25 & 240 & 10.4 \\
\hline Females & 10 & 53 & 18.9 & 15 & 51 & 29.4 & 25 & 104 & 24.0 \\
\hline \multicolumn{10}{|c|}{$A C$} \\
\hline Males & 22 & 350 & 6.3 & 77 & 465 & 16.6 & 99 & 815 & 12.1 \\
\hline Females & 26 & 173 & 15.0 & 37 & 205 & 18.0 & 63 & 378 & 16.7 \\
\hline \multicolumn{10}{|c|}{$\mathrm{APE}$} \\
\hline Males & 3 & 77 & 3.9 & 18 & 109 & 16.5 & 21 & 186 & 11.3 \\
\hline Females & 2 & 51 & 3.9 & 8 & 77 & 10.4 & 10 & 128 & 7.8 \\
\hline Total & 66 & 797 & 8.3 & 177 & 1,054 & 16.8 & 243 & 1,851 & 13.1 \\
\hline
\end{tabular}


TABLE 5. P values from the chi-square analyses between sexes and between compounds ${ }^{1}$

\begin{tabular}{|c|c|c|c|c|c|c|c|c|c|}
\hline & \multicolumn{3}{|c|}{ Caries } & \multicolumn{3}{|c|}{ AMTL } & \multicolumn{3}{|c|}{ Periapical defects } \\
\hline & Interior & Posterior & Total & Anterior & Posterior & Total & Anterior & Posterior & Total \\
\hline \multicolumn{10}{|c|}{ Analysis within compounds ${ }^{2}$} \\
\hline \multicolumn{10}{|c|}{$\mathrm{ACA}$} \\
\hline $\mathrm{M} v s \mathrm{~F}$ & ** & ** & $* *$ & n.s. & $* *$ & * & $* *$ & * & ** \\
\hline \multicolumn{10}{|c|}{$\mathrm{AC}$} \\
\hline $\mathrm{M}(\mathrm{E})$ vs $\mathrm{M}(\mathrm{L})$ & & & & * & * & $* *$ & & & \\
\hline $\mathrm{M}(\mathrm{E})$ vs $\mathrm{F}$ & & & & n.s. & n.s. & n.s. & & & \\
\hline $\mathrm{M}(\mathrm{L})$ vs $\mathrm{F}$ & & & & $* *$ & $* *$ & $* *$ & & & \\
\hline $\mathrm{M}$ vs $\mathrm{F}$ & ** & $* *$ & $* *$ & & & & $* *$ & n.s. & * \\
\hline \multicolumn{10}{|c|}{$\mathrm{APE}$} \\
\hline $\mathrm{M} v s \mathrm{~F}$ & n.s. & n.s. & n.s. & n.s. & n.s. & n.s. & n.s. & n.s. & n.s. \\
\hline \multicolumn{10}{|c|}{ Analysis within sex ${ }^{2}$} \\
\hline \multicolumn{10}{|c|}{ Males } \\
\hline $\mathrm{ACA}$ vs $\mathrm{AC}(\mathrm{E})$ & & & & n.s. & ** & ** & & & \\
\hline ACA vs AC(L) & & & & n.s. & n.s. & n.s. & & & \\
\hline $\mathrm{APE}$ vs $\mathrm{AC}(\mathrm{E})$ & & & & * & * & $* *$ & & & \\
\hline $\mathrm{APE}$ vs $\mathrm{AC}(\mathrm{L})$ & & & & n.s. & n.s. & n.s. & & & \\
\hline ACA vs APE & * & * & * & * & n.s. & n.s. & n.s. & n.s. & n.s. \\
\hline ACA vs AC & n.s. & n.s. & n.s. & & & & n.s. & n.s. & n.s. \\
\hline $\mathrm{APE} v \mathrm{~A} \mathrm{AC}$ & n.s. & n.s. & n.s. & & & & n.s. & n.s. & n.s. \\
\hline \multicolumn{10}{|c|}{ Females } \\
\hline ACA vs AC & n.s. & n.s. & n.s. & & & & n.s. & n.s. & n.s. \\
\hline ACA vs APE & $* *$ & $* *$ & $* *$ & & & & $* *$ & $* *$ & $* *$ \\
\hline $\mathrm{APE} v s \mathrm{AC}$ & ** & ** & $* *$ & & & & $* *$ & $* *$ & ** \\
\hline
\end{tabular}

${ }^{1}$ The AC compound is the only one where males were kept separate according to chronology: $\mathrm{M}(\mathrm{E})$ stands for males Early period, $\mathrm{M}(\mathrm{L})$ for males Late period. Females were all pooled together.

${ }^{2}$ n.s. $=\mathrm{P}>0.05 ;^{*}=0.05 \geq \mathrm{P}>0.01 ;^{* *}=\mathrm{P} \leq 0.01$ ( $\left.1 \mathrm{df}\right)$.

Landa D de. 1978 (1566). Relación de las cosas de Yucatán. Porrúa: Mexico.

Larsen CS. 1997. Bioarchaeology. Cambridge: Cambridge University Press.

Larsen CS, Shavit R, Griffin MC. 1991. Dental caries evidence for dietary change. In: Kelley MA, Larsen CS, editors. Advances in dental anthropology. New York, Wiley Liss. p 179-202.

Lee RB, DeVore I. 1968. Man the hunter. Chicago: Aldine.

Lents DL. 1991. Maya diets of the rich and poor: paleoethnobotanical evidence from Copán. Lat Am Antiq 2:269-287.

Lukacs JR. 1989. Dental paleopathology: methods for reconstructing dietary patterns. In: Iscan MY, Kennedy KAR, editors. Reconstructing life from the skeleton. New York: Wiley Liss. p 261-286.

Marafon G. 1976. Odontoiatria. Roma: ALMES.

Metress JF, Conway T. 1975. Standardized system for recording dental caries in prehistoric skeletons. J Dent Res, 54: 908.
Powell ML. 1985. The analysis of dental wear and caries for dietary reconstruction. In: Gilbert RI, Mielke LJ, editors. The analysis of prehistoric diets. New York: Academic Press. p 307-338.

Sanders WT, Price BJ. 1968. Mesoamerica: the evolution of a civilization. New York: Random House.

Sierra Sosa TN. 1999. Xcambó. Codiciado puerto del Clásico Maya. INAJ Semilla de Maíz. Conaculta, INAH. 10.

Sierra Sosa TN, Martínez Lizarraga A. 2001. Los entierros de Xcambó y sus implicaciones socials. INAJ Semilla de Maiz. Conaculta, INAH 12:6-12.

Storey R. 1999. Late classic nutrition and skeletal indicators at Copán, Honduras. In: White CD, editor. Reconstructing ancient Maya diet. Salt Lake City: The University of Utah Press. p 169-179.

Whittington SL. 1999. Caries and ante mortem tooth loss at Copán. Implications for commoner diet. In: White CD, editor. Reconstructing ancient Maya diet. Salt Lake City: The University of Utah Press. p 151167. 
White CD. 1997. Ancient diet at Lamanai and Pacbitun: implication for the ecological model of collapse. In: Whittington SL, Reed DM, editors. Bones of the Maya: studies of ancient skeletons. Washington: Smithsonian Institution Press. p 171-180.

White CD, ed. 1999. Reconstructing ancient Maya diet. Salt Lake City: The University of Utah Press.

Whittington SL, Reed DM, editors. 1997a. Bones of the Maya: studies of ancient skeletons. Washington: Smithsonian Institution Press.

Whittington SL, Reed DM. 1997b. Commoner diet at Copán: insights from stable isotopes and porotic hyperostosis. In: Whittington SL, Reed DM, editors.
Bones of the Maya: studies of ancient skeletons. Washington: Smithsonian Institution Press. p 157170.

Whittington SL. 1999. Caries and antemortem tooth loss at Copán: implications for commoner diet. In: White $\mathrm{CD}$, editor. Reconstructing ancient Maya diet. Salt Lake City: The University of Utah Press. p 151-167.

\section{Decoding Your Subscription}

Want to know when your subscription to Dental Anthropology expires? Membership in the Association and, thus, your subscription to Dental Anthropology is on an annual basis coinciding with the calendar year. Have a look at the mailing label on the evelope that this issue arrived in, and you will see the year for which your dues have been paid. The year is located in parentheses to the right of your name. So, if the mailing label says "(2003)" you are paid to the end of this calendar year.

In order to extend your membership, fill-out the relevant portions of the enclosed renewal form - remember to include appropriate payment-and mail it to the Secretary-Treasurer of the Association:

$$
\begin{aligned}
& \text { Dr. Diane Hawkey } \\
& \text { Department of Anthropology } \\
& \text { Arizona State University } \\
& \text { Tempe, Arizona 85287-2402 USA } \\
& \text { e-mail: hawkey@asu.edu }
\end{aligned}
$$

